\title{
Characteristics and treatment outcomes of HIV infected elderly patients enrolled in Kisii Teaching and Referral Hospital, Kenya
}

\author{
Benuel Nyagaka ${ }^{1}$; Stanslaus Kiilu Musyoki ${ }^{1}$; Lucy Karani ${ }^{1}$; Anthony Kebira Nyamache ${ }^{2}$
}

1. School of health sciences, Kisii University, P.O Box 408-40200, Kisii, Kenya

2. Department of Microbiology, School of Pure and Applied Sciences, Kenyatta University, P.O. Box 43844 (00100), Nairobi, Kenya

\section{Emails:}

Stanslaus K Musyoki: stanstylo@gmail.com; Lucy Karani: lucynyauma@gmail.com; Anthony K Nyamache: akibera2000@gmail.com or nyamache.athony@ku.ac.ke

\begin{abstract}
Background: A better understanding of the baseline characteristics of elderly people living with HIV/AIDS (PLWHA) is relevant because the world's HIV population is ageing.

Objectives: This study aimed to evaluate the baseline characteristics of PLWHA aged $\geq 50$ years at recruitment to HIV/ AIDS clinic compared against the viral load (VL) and CD4 count among patients attending Kisii Teaching and Referral Hospital (KTRH), Kenya.

Methods: We retrospectively evaluated temporal inclinations of CD4 levels, viral load change and baseline demographic characteristics in the electronic records at the hospital using a mixed error-component model for 1329 PLWHA attending clinic between January 2008 and December 2019.

Results: Findings showed a significant difference in the comparison between baseline VL and WHO AIDS staging ( $\mathrm{p}=0.026)$. Overall VL levels decreased over the period significantly by WHO AIDS staging $(\mathrm{p}<0.0001)$. Significant difference was observed by gender $(p<0.0001)$, across age groups $(p<0.0001)$ and baseline CD4 counts $(p=0.003)$. There were significant differences in WHO staging by CD4 count $>200$ cell $/ \mathrm{mm} 3(\mathrm{p}=0.048)$ and residence $(\mathrm{p}=0.001)$.

Conclusion: Age, WHO AIDS staging, gender and residence are relevant parameters associated with viral load decline and CD4 count in elderly PLWHA. A noticeable VL suppression was attained confirming possible attainment of VL suppression among PLWHA under clinical care.
\end{abstract}

Keywords: HIV infected elderly patients; Kisii Teaching and Referral Hospital, Kenya.

DOI: https://dx.doi.org/10.4314/ahs.v20i4.6

Cite as: Nyagaka B, Musyoki SK, Karani L, Nyamache AK. Characteristics and treatment outcomes of HIV infected elderly patients enrolled in Kisii Teaching and Referral Hospital, Kenya. Afri Health Sci. 2020;20(4):1537-45. https://dx.doi. org/10.4314/ahs.v20i4.6

\section{Introduction}

Administration of antiretroviral therapy (ART) among human immunodeficiency virus (HIV) infected patients has led to increased survival rates among PLWHA. ${ }^{1}$ It is projected that by 2040, the number of PLWHA aged $\geq 50$ years will have grown by nearly three times in Sub-Saharan Africa (SSA) from an estimated 3.1 million in 2011 to 9.1 million $^{2}$. With increasing access to ART across populations, there will be a need for long-term ART care. ${ }^{3,4}$ Previous studies from developed countries

\section{Corresponding author: \\ Benuel Nyagaka, \\ P.O Box 408-40200, Kisii \\ Phone- 0720452914 \\ Email: benuelnyagaka@yahoo.com}

have shown distinct characteristics at diagnosis and clinical outcomes among PLWHA aged $\geq 50$ years compared to younger PLWHA. ${ }^{5}$

There are few research findings in SSA on the indicative features of HIV infection in PLWHA aged $\geq 50$ years receiving ART. ${ }^{6,7,8}$ Additionally, the restricted number studies that portray baseline indicative features, immunological response and mortality in elderly PLWHA have a limitation of small sample sizes. ${ }^{9,10}$ On account of this immediate information gap, furnishing supplementary data on the baseline indicative features of HIV infection among elderly PLWHA in sub-Saharan Africa is necessary. This study reports on the baseline characteristics of elderly PLWHA in Kenya which has not been addressed by previous studies. The purpose License (https://creativecommons.org/licenses/BY/4.0), which permits unrestricted use, distribution, and reproduction in any medium, provided the original work is properly cited. 
of our investigation was to examine baseline VL and CD4 count among people aged $\geq 50$ years at the time of recruitment and identify disparities, if any, by gender, age group, current residence, WHO staging, patient source, and marital status in patients attending HIV/ AIDS clinic at KTRH.

\section{Materials and Methods \\ Study Area}

The study was conducted at HIV care clinics of KTRH.

\section{Study Design and Data Collection}

This study was a cross-sectional retrospective study using secondary electronic data obtained from HIV patients visiting an HIV/AIDS clinic at KTRH. Data on baseline CD4 count, baseline VL, last reported VL, WHO status, age, gender, marital status, the point at which individual patient source and residence was collected retrospectively from the electronic data maintained at from at KTRH.

Demographics: Age was categorised as 50-59/60$69 / 70-79 / \geq 80$ years. Age was determined based on the age of the individual at the time of enrolment to the clinic. The current residence was categorised as urban or rural as previously defined. ${ }^{11}$ Gender was categorised as male or female while marital status was married/cohabiting, divorced or widowed. Patient Source was categorised as an outpatient, Prevention of mother-to-child transmission (PMTCT), Tuberculosis (TB), inpatient or Voluntary Counselling and Testing (VCT) clinics while WHO AIDS Staging was stage I/II/III/IV.
CD4 count and viral load: The baseline CD4 cell counts were placed in four categories as previously described, ${ }^{12,13,14}$ while VLs were classified into two guided by the previous related study. ${ }^{15}$ All undetectable VL values reported during the study period were replaced with 200 copies/mL following the CDC guideline. ${ }^{16}$

\section{Ethical considerations}

University of Eastern Africa, Baraton research ethics committee, Ministry of Health, Ministry of Education and National Commission for Science, Technology and Innovation of Kenya approved this study.

\section{Statistical analysis}

Descriptive statistics were used to examine baseline CD4 count, VL and demographic characteristics. Continuous measures were compared using the Kruskal-Wallis. Wilcoxon signed-rank test was performed to compare first and last, VL counts by demographics. The p-values $\leq 0.05$ were considered statistically significant. All analyses were performed using SAS version 9.3.

\section{Results}

Baseline CD4 counts, VL measurements and demographic characteristics of the study population were summarised (Table 1).

Comparison of baseline characteristics by gender was determined (Table 2). Statistically significant differences were found in gender and median age $(p<0.0001)$ and in gender and age groups $(\mathrm{P}<0.0001)$. Statistically significant differences were found in gender and CD4 categories $(p=0.003)$. 
Table 1: Demographic Characteristics, CD4 Count and HIV Viral Load of PLWHA

\begin{tabular}{ll}
\hline Characteristics & Frequency $\mathbf{( \% )}$ \\
\hline Gender & \\
Male & $547(41.2)$ \\
Female & $782(58.8)$ \\
Age group & \\
$50-59$ & $934(70.3)$ \\
$60-69$ & $332(25.0)$ \\
$70-79$ & $60(4.5)$ \\
$\geq 80$ & $3(0.2)$ \\
Marital Status & \\
Married/cohabiting & $1001(75.3)$ \\
Divorced & $96(7.2)$ \\
Widowed & $232(17.5)$ \\
Residence & \\
Urban & $562(42.3)$ \\
Rural & $767(57.7)$ \\
Patient Source & \\
Outpatient & $1057(79.5)$ \\
PMTCT & $62(4.7)$ \\
TB clinic & $70(5.3)$ \\
Inpatient & $61(4.6)$ \\
VCT & $79(5.9)$ \\
WHO Staging & \\
I & $556(41.8)$ \\
II & $455(34.2)$ \\
III & $295(22.2)$ \\
IV & $23(1.7)$ \\
CD4 count & $320(24.1)$ \\
201-350cells/mm & \\
351-500cells $/ \mathrm{mm}^{3}$ & $243(18.3)$ \\
B500cells $/ \mathrm{mm}^{3}$ & $399(30.0)$ \\
Baseline VL & $367(27.6)$ \\
>10000copies $/ \mathrm{mL}^{3}$ & \\
\hline & $1244(93.6)$ \\
& $85(6.4)$ \\
\hline
\end{tabular}

First CD4 and VL counts were defined as the first available value at the database. 
Table 2: Comparisons Of Baseline Characteristics By Gender.

\begin{tabular}{|c|c|c|c|c|}
\hline Variable & $\begin{array}{l}\text { Overall } \\
(N=1329)\end{array}$ & $\begin{array}{l}\text { Male } \\
(N=547) \\
\end{array}$ & $\begin{array}{l}\text { Female } \\
(N=782) \\
\end{array}$ & P-Value \\
\hline Mean Age(IQR) & $57(50-89)$ & $58(50-89)$ & $56(50-83)$ & $<0.001$ \\
\hline \multicolumn{5}{|l|}{ Age group } \\
\hline $50-59$ & 934 & 339 & 595 & \multirow[t]{4}{*}{$<0.001$} \\
\hline $60-69$ & 332 & 173 & 159 & \\
\hline $70-79$ & 60 & 34 & 26 & \\
\hline$\geq 80$ & 3 & 1 & 2 & \\
\hline \multicolumn{5}{|l|}{ Marital Status } \\
\hline Married/cohabiting & 1001 & 413 & 588 & \multirow[t]{3}{*}{0.433} \\
\hline Divorced & 96 & 34 & 62 & \\
\hline Widowed & 232 & 100 & 132 & \\
\hline \multicolumn{5}{|l|}{ Residence } \\
\hline Urban & 562 & 221 & 341 & \multirow[t]{2}{*}{0.134} \\
\hline Rural & 767 & 326 & 441 & \\
\hline \multicolumn{5}{|l|}{ Patient Source } \\
\hline Outpatient & 1057 & 431 & 626 & \multirow[t]{5}{*}{0.973} \\
\hline PMTCT & 62 & 27 & 35 & \\
\hline TB clinic & 70 & 31 & 39 & \\
\hline Inpatient & 61 & 25 & 36 & \\
\hline VCT & 79 & 33 & 46 & \\
\hline \multicolumn{5}{|l|}{ WHO staging } \\
\hline I & 556 & 239 & 317 & \multirow[t]{4}{*}{0.126} \\
\hline II & 455 & 195 & 260 & \\
\hline III & 295 & 106 & 189 & \\
\hline IV & 23 & 7 & 16 & \\
\hline \multicolumn{5}{|l|}{ Baseline CD4 count } \\
\hline$\leq 200$ cells $/ \mathrm{mm}^{3}$ & 320 & 158 & 162 & \multirow[t]{4}{*}{0.003} \\
\hline 201-350cells $/ \mathrm{mm}^{3}$ & 243 & 98 & 145 & \\
\hline $351-500$ cells $/ \mathrm{mm}^{3}$ & 399 & 160 & 239 & \\
\hline$>500$ cells $/ \mathrm{mm}^{3}$ & 367 & 131 & 236 & \\
\hline \multicolumn{5}{|l|}{ Baseline VL } \\
\hline$\leq 10000$ copies $/ \mathrm{mL}$ & 1244 & 510 & 734 & \multirow[t]{2}{*}{0.363} \\
\hline$>10000$ copies/mL & 85 & 37 & 48 & \\
\hline
\end{tabular}

The p-value represents the comparison of the population baseline characteristics by gender.

Comparison of baseline characteristics by baseline CD4 cell count was determined (Table 3). Statistically significant differences were found in baseline CD4 count and
WHO staging ( $\mathrm{P}=0.048)$. Statistically significant differences were also found in baseline CD4 count by gender $(\mathrm{P}=0.003)$. 
Table 3: Comparison Of Baseline Characteristics By CD4 Count

\begin{tabular}{|c|c|c|c|c|c|c|}
\hline \multirow[b]{2}{*}{ Variable } & \multicolumn{5}{|c|}{ Mean CD4 count(cell/mm3) categories } & \multirow[b]{2}{*}{$\begin{array}{l}P \text { - } \\
\text { Value }\end{array}$} \\
\hline & $\begin{array}{l}\text { Total } \\
(N=1329)\end{array}$ & $\begin{array}{l}\leq 200 \\
(N=320)\end{array}$ & $\begin{array}{l}201-350 \\
(N=243)\end{array}$ & $\begin{array}{l}351-500 \\
(N=399)\end{array}$ & $\begin{array}{l}>500 \\
(N=367)\end{array}$ & \\
\hline \multicolumn{7}{|l|}{ Age Groups } \\
\hline $50-59$ & 934 & 211 & 186 & 284 & 253 & 0.152 \\
\hline $60-69$ & 332 & 93 & 50 & 99 & 90 & \\
\hline $70-79$ & 60 & 16 & 7 & 15 & 22 & \\
\hline$\geq 80$ & 3 & 0 & 0 & 1 & 2 & \\
\hline \multicolumn{7}{|l|}{ Marital Status } \\
\hline Married/cohabiting & 1001 & 251 & 177 & 297 & 276 & 0.524 \\
\hline Divorced & 96 & 22 & 18 & 25 & 31 & \\
\hline Widowed & 232 & 47 & 48 & 77 & 60 & \\
\hline \multicolumn{7}{|l|}{ Residence } \\
\hline Urban & 562 & 124 & 100 & 187 & 151 & 0.145 \\
\hline Rural & 767 & 196 & 143 & 212 & 216 & \\
\hline \multicolumn{7}{|l|}{ Patient Source } \\
\hline Outpatient & 1057 & 251 & 198 & 321 & 287 & 0.832 \\
\hline PMTCT & 62 & 14 & 13 & 15 & 20 & \\
\hline TB clinic & 70 & 16 & 8 & 25 & 21 & \\
\hline Inpatient & 61 & 15 & 13 & 16 & 17 & \\
\hline VCT & 79 & 24 & 11 & 22 & 22 & \\
\hline \multicolumn{7}{|l|}{ WHO staging } \\
\hline I & 556 & 135 & 79 & 188 & 154 & 0.048 \\
\hline II & 455 & 112 & 101 & 113 & 129 & \\
\hline III & 295 & 67 & 59 & 90 & 79 & \\
\hline IV & 23 & 6 & 4 & 8 & 5 & \\
\hline $\begin{array}{l}\text { Baseline viral } \\
\text { load }\end{array}$ & & & & & & \\
\hline$\leq 10000$ copies $/ \mathrm{ml}$ & 1244 & 299 & 232 & 371 & 342 & 0.616 \\
\hline$>10000$ copies $/ \mathrm{ml}$ & 85 & 21 & 11 & 28 & 25 & \\
\hline \multicolumn{7}{|l|}{ Gender } \\
\hline Male & 547 & 158 & 98 & 160 & 131 & 0.003 \\
\hline Female & 782 & 162 & 145 & 239 & 236 & \\
\hline
\end{tabular}

Comparison of baseline characteristics by WHO AIDS Staging was determined (Table 4). Statistically significant differences were found in WHO staging by base- line CD4 count categories $(\mathrm{P}=0.048)$. Statistically significant differences were found in WHO staging by residence $(\mathrm{P}=0.001)$ and $\mathrm{WHO}$ staging by baseline VL $(\mathrm{P}=0$.026). 
Table 4: Comparison of Baseline Characteristics by WHO AIDS Staging.

\begin{tabular}{|c|c|c|c|c|c|c|}
\hline \multirow{2}{*}{ Variable } & \multicolumn{5}{|c|}{ WHO AIDS Staging } & \multirow{2}{*}{ P-Value } \\
\hline & $\begin{array}{l}\text { Total } \\
(\mathrm{N}=1329)\end{array}$ & $\begin{array}{l}I \\
(\mathrm{~N}=556)\end{array}$ & $\begin{array}{l}\text { II } \\
(\mathrm{N}=455)\end{array}$ & $\begin{array}{l}\text { III } \\
(\mathrm{N}=295)\end{array}$ & $\begin{array}{l}\text { IV } \\
(\mathrm{N}=\mathbf{2 3})\end{array}$ & \\
\hline \multicolumn{7}{|l|}{ Age Groups } \\
\hline $50-59$ & 934 & 388 & 312 & 221 & 13 & \multirow{4}{*}{0.284} \\
\hline $60-69$ & 332 & 142 & 119 & 61 & 10 & \\
\hline $70-79$ & 60 & 24 & 24 & 12 & 0 & \\
\hline$\geq 80$ & 3 & 2 & 0 & 1 & 0 & \\
\hline \multicolumn{7}{|l|}{ Marital Status } \\
\hline Married/cohabiting & 1001 & 419 & 335 & 229 & 18 & \multirow{3}{*}{0.649} \\
\hline Divorced & 96 & 42 & 34 & 17 & 3 & \\
\hline Widowed & 232 & 95 & 86 & 49 & 2 & \\
\hline \multicolumn{7}{|l|}{ Residence } \\
\hline Urban & 562 & 268 & 170 & 112 & 12 & \multirow{2}{*}{0.001} \\
\hline Rural & 767 & 288 & 285 & 183 & 11 & \\
\hline \multicolumn{7}{|l|}{ Patient Source } \\
\hline Outpatient & 1057 & 439 & 362 & 238 & 18 & \multirow[t]{5}{*}{0.944} \\
\hline PMTCT & 62 & 28 & 18 & 15 & 1 & \\
\hline TB clinic & 70 & 27 & 28 & 13 & 2 & \\
\hline Inpatient & 61 & 25 & 21 & 15 & 0 & \\
\hline VCT & 79 & 37 & 26 & 14 & 2 & \\
\hline \multicolumn{7}{|l|}{ CD4 count } \\
\hline$\leq 200$ & 320 & 135 & 112 & 67 & 6 & \multirow[t]{4}{*}{0.048} \\
\hline $201-350$ & 243 & 79 & 101 & 59 & 4 & \\
\hline $351-500$ & 399 & 188 & 113 & 90 & 8 & \\
\hline$>500$ & 367 & 154 & 129 & 79 & 5 & \\
\hline \multicolumn{7}{|l|}{ Baseline VL } \\
\hline$\leq 10000$ copies $/ \mathrm{mL}$ & 1244 & 521 & 428 & 277 & 18 & \multirow[t]{2}{*}{0.026} \\
\hline$>10000$ copies $/ \mathrm{mL}$ & 85 & 35 & 27 & 18 & 5 & \\
\hline \multicolumn{7}{|l|}{ Gender } \\
\hline Male & 547 & 239 & 195 & 106 & 7 & \multirow[t]{2}{*}{0.126} \\
\hline Female & 782 & 317 & 260 & 189 & 16 & \\
\hline
\end{tabular}

The p-value represents the comparison of populations by WHO AIDS staging.

Comparison of the baseline characteristics by VL cant differences in changes in VL and were found by change was determined (Table 5). Statistically signifi- WHO staging $(\mathrm{p}<0.0001)$. 
Table 5: Comparison Of Baseline Characteristics by Change in Viral Load

\begin{tabular}{|c|c|c|c|c|}
\hline \multirow{2}{*}{ Variables } & \multicolumn{4}{|c|}{ Mean Viral load(copies/mL) } \\
\hline & Baseline & Last & Difference & $p$-Value \\
\hline \multicolumn{5}{|l|}{ Gender } \\
\hline Male & 6588.1335 & 71.7788 & 6530.3333 & 0.455 \\
\hline Female & 5092.1228 & 50.0358 & 5032.9182 & \\
\hline \multicolumn{5}{|l|}{ Age Group } \\
\hline $50-59$ & 4473.3073 & 51.0418 & 4426.8746 & 0.275 \\
\hline $60-69$ & 8927.2440 & 83.0060 & 8826.3705 & \\
\hline $70-79$ & 7389.6833 & 50.2167 & 7339.4667 & \\
\hline$\geq 80$ & 151.3333 & 49.0000 & 102.3333 & \\
\hline \multicolumn{5}{|l|}{ Marital Status } \\
\hline Married/Cohabiting & 5358.9670 & 62.2338 & 5295.8430 & 0.637 \\
\hline Divorced & 8978.2292 & 49.0000 & 8930.3750 & \\
\hline Widowed & 5707.8623 & 58.9850 & 5810.9698 & \\
\hline \multicolumn{5}{|l|}{ Residence } \\
\hline Urban & 5676.8577 & 49.1174 & 5637.8788 & 0.993 \\
\hline Rural & 5707.8623 & 58.9850 & 5656.3937 & \\
\hline \multicolumn{5}{|l|}{ Patient Source } \\
\hline Outpatient & 6226.5043 & 61.5109 & 6159.1599 & 0.704 \\
\hline PMTCT & 365.3387 & 49.0000 & 316.2097 & \\
\hline TB clinic & 4151.4143 & 49.2714 & 4102.4143 & \\
\hline Inpatient & 2766.1475 & 49.0000 & 2717.1639 & \\
\hline VCT & 6612.0127 & 49.3418 & 6648.0897 & \\
\hline WHO & & & & \\
\hline \multicolumn{5}{|l|}{ Staging } \\
\hline I & 4582.6241 & 51.4209 & 4530.3309 & $<0.001$ \\
\hline II & 5024.2220 & 73.9187 & 4937.3824 & \\
\hline III & 5527.4814 & 50.8576 & 5496.1769 & \\
\hline IV & 48747.0435 & 50.6522 & 48698.0435 & \\
\hline \multicolumn{5}{|l|}{ CD4 count } \\
\hline$\leq 200$ & 7405.5281 & 53.9969 & 7349.7531 & 0.446 \\
\hline $201-350$ & 3761.1564 & 49.4897 & 3687.4239 & \\
\hline $351-500$ & 6997.6967 & 77.2005 & 6937.9724 & \\
\hline$>500$ & 4114.2725 & 49.8174 & 4065.4659 & \\
\hline
\end{tabular}

\section{Discussion}

We report baseline demographic characteristics, CD4 counts and VL for PLWHA aged $\geq 50$ years first-time HIV testers who were ART-naive and diagnosed with HIV. Majority of the PLWHA were originally tested at the outpatient clinic. The explanation could be that most people are unwilling to test for HIV and only get a reason to test when visiting health centres where they are recommended to take HIV test and the out-patient clinic is visited by most patients who seek treatment. Overall, the HIV epidemic among the elderly who visited KTRH was dominated by adults aged 50-59years whose proportion was higher when compared to the national proportions ${ }^{17}$ for the same age group. The proportion of females was also higher compared to males which do not mimic the national inclination where the proportion of males is higher than females. ${ }^{17}$ This observation is because treatment guidelines have changed to emphasise early diagnosis, treatment, and attachment to care with a result that more individuals are receiving ART. ${ }^{12}$ Findings also show that the highest poportion of PLWHA aged $\geq 50$ years attending HIV/AIDS clinic are married/cohabiting. A feasible explanation is that by age of 24.8 years most Kenyans are married. ${ }^{18}$

In the stated study period VL declined. Among the reasons for this observation is that the current ART regimens have been improved and are more comfortably endured. It is also plausible that patients with higher VL die earlier and the people who remain have lower VL. ${ }^{12}$ We observed a higher decline in VL among PLWHA in WHO AIDS stages III/IV as compared to WHO AIDS stages I/II. Probably this is because many individuals with WHO AIDS stages I/II may have entered the study with lower VLs compared to those at stage III/IV making it difficult to detect any additional VL decline in this group. There were significantly more 
individuals whose baseline VL was $\leq 10000$ copies $/ \mathrm{mL}$ at recruitment just as there were more individuals in WHO AIDS stages I/II. This again can be explained by a change in treatment guidelines as explained above. When we adjusted VL for age group and WHO AIDS staging, we observed fewer individuals in the age groups 70 years and above. This could be explained by natural attrition with an increase in age. Life expectancy in Kenya is 66.7 years. ${ }^{19}$

There was a significantly higher number of females in each CD4 category which was not clear. Notwithstanding some studies suggest that the probability of late testing for HIV is higher for men compared to females. ${ }^{20,21}$ Higher number of individuals in WHO AIDS stages I/II/III was observed to have rural residence. It is plausible that most people aged $\geq 50$ years could have retired and relocated to rural homes at least for the Kenyan case.

There were some limitations in our study. Data was not available for PLWHA who dropped out of care and those who were not tested. Our study did not include co-morbidities which impinge HIV treatment particularly in PLWHA aged $\geq 50$ years. ${ }^{22}$

\section{Conclusion and recommendations}

This study uncovered unavoidable indicative features (Age, WHO AIDS stages, Gender and Residence) as associated factors to CD4 count and VL decline. Therefore CD4 count, VL, age, WHO AIDS stages, gender and residence should be utilised in solving health care challenges associated with elderly PLWHA. Additionally, Noticeable VL suppression was attained during the study period confirming possible attainment of VL suppression among elderly PLWHA under clnical care.

\section{Acknowledgements}

We acknowledge Kisii University for reviewing this document and allowing use of its infrastructure in the process of undertaking this thesis. We also acknowledge Hary Fanjo from Becton Dickinson Kenya, Philip Mosioma from Kisii National Polytechnic and the Kisii Teaching Referral Hospital staff for their technical support.

\section{Author Disclosure Statement}

All the authors declare no conflict of interest.

\section{References}

1. Autenrieth CS, Beck EJ, Stelzle D, Mallouris C, Mahy M, Ghys P. "Global and Regional Trends of People Liv- ing with HIV Aged 50 and over : Estimates and Projections for 2000-2020.” PLoS One 2018;13(11):1-11.

2. Kharsany AB, Karim QA. "HIV Infection and AIDS in sub-Saharan Africa: Current Status, Challenges and Opportunities." The Open AIDS Journal 2016; 8(10):3448.

3. Kiplagat J, Mwangi A, Keter A et al. "Retention in Care among Older Adults Living with HIV in Western Kenya: A Retrospective Observational Cohort Study." PLoS One. 2018; 28:13(3)

4. Nansseu JRN, Jean JRB. “Antiretroviral Therapy Related Adverse Effects: Can Sub-Saharan Africa Cope with the New 'Test and Treat' Policy of the World Health Organization?" Infectious Diseases of Poverty. 2017; 6:24.

5. Tweya H, Feldacker C, Heller T. et al. "Characteristics and Outcomes of Older HIVInfected Patients Receiving Antiretroviral Therapy in Malawi: A Retrospective Observation Cohort Study." PLoS One. 2017; 12(7)

6. Negin J, Martiniuk A, Cumming RG et al. "Prevalence of HIV and Chronic Comorbidities among Older Adults" AIDS 2012; 157(5):325-35

7. Martin CP, Fain MJ, Klotz SA. "The Older HIV-Positive Adult: A Critical Review of the Medical Literature." American Journal of Medicine 2008; 121(12):1032-7

8. Aboderin IAG, Beard JR. "Older People's Health in Sub-Saharan Africa.” The Lancet. 2015; 385(9968)

9. Semeere AS, Lwanga I, Sempa J et al. "Mortality andImmunological Recovery among Older Adults on Antiretroviral Therapy at a Large Urban HIV Clinic in Kampala, Uganda." Journal of Acquired Immune Deficiency Syndromes. 2014; 67(4):382-9

10. Maskew M, Brennan AT, MacPhail AP, Sanne IM, Fox MP. "Poorer ART Outcomes with Increasing Age at a Large Public Sector HIV Clinic in Johannesburg, South Africa." Journal of the International Association of Physicians in AIDS Care 2012; 11(1):57-65

11. United Nations, Department of Economic and Social Affairs, Population Division (2019). World Urbanization Prospects: The 2018 Revision (ST/ESA/ SER.A/420). New York: United Nations.

12. Chakraborty H, Medha I, Wayne AD, Ashok VS, Helmut A, Aron W. "Disparities in Viral Load and CD4 Count Trends among HIV-Infected Adults in South Carolina." AIDS Patient Care and STDs 2015; 29(1):2632

13. Li X, Margolick J, Jamieson B, Rinaldo C, Phair J, Jacobson L. "CD4++ T-Cell Counts and Plasma HIV-1 RNA Levels beyond 5 Years of Highly Active Antiretroviral Therapy." Journal of Acquired Immune Deficiency Syndromes. 2011; 57(5):421-428. 
14. Pereira MF, Luz E, Netto EM, Barbosa MHF, Brites C. "Low Variation in Initial CD4 Cell Count in a HIV Referral Center, in Salvador, Brazil, from 2002 to 2015." Brazilian Journal of Infectious Diseases 2018;22(3):245-247 15. Murnane PM, Hughes JP, Celum C et al. "Using Plasma Viral Load to Guide Antiretroviral Therapy Initiation to Prevent HIV-1 Transmission." PLoS One 2012; 7(11)

16. Centers for Disease Control and Prevention. Guidance on Community Viral Load: A Family of Measures, Definitions, and Method for Calculation. 2011.

17. National AIDS and STI Control Programme (NASCOP), Kenya. Kenya AIDS Indicator Survey 2012: Final Report. Nairobi, NASCOP. 2014.

18. United Nations, Department of Economic and Social Affairs, Population Division. World Fertility Report
2013: Fertility at the Extremes (United Nations publication). 2014

19. United Nations, Department of Economic and Social Affairs, Population Division. World Mortality 2019: Data Booklet (ST/ ESA/SER.A/436). 2019

20. Hall HI, Frazier EL, Rhodes P, et al. "Differences in Human Immunodeficiency Virus Care and Treatment among Subpopulations in the United States." JAMA Internal Medicine 2013; 173(14):1337-44

21. Muthulingam D, Chin J, Hsu L, Scheer S, Schwarcz S. "Disparities in Engagement in Care and Viral Suppression among Persons with HIV." Journal of Acquired Immune Deficiency Syndromes 2013; 63(1):112-9

22. Warren-Jeanpiere L, Dillaway H, Hamilton P, Young M, Goparaju L. "Taking It One Day at a Time: African American Women Aging with Hiv and Co-Morbidities." AIDS Patient Care and STDs 2014; 28(7):372-80 